\title{
"But My Students All Speak English": Ethical Research Issues of Aboriginal English
}

Lynne Wiltse

In this article I explore ethical issues in relation to the topic of Aboriginal students who speak a dialect of English. Taking the form of a retrospective inquiry, I draw on data from an earlier study that examined Aboriginal English in the broader context of Aboriginal language loss and revival. Three interrelated ethical issues are discussed: the relationship between the dialect spoken by Aboriginal students and the ancestral language they no longer speak; the educational implications of Aboriginal English-speakers in the classroom; and insider-outsider issues of a non-Aboriginal English-speaking researcher working in the areas of Aboriginal education and language. I also review the recent literature in the field of Aboriginal English and outline changes that have occurred in classroom practice. Whereas in the past the common aim was to eliminate the home dialect, the goal of current programs is to add Standard English as an additional dialect to students' repertoires of linguistic varieties. Suggestions are offered for educators interested in using a bi-dialectal approach in the classroom.

Dans cet article, je me penche sur des enjeux d'éthique relatifs aux élèves autochtones qui parlent un dialecte de l'anglais. Sous forme d'une enquête rétrospective, je puise dans des données d'une étude antérieure qui a examiné l'anglais autochtone dans le contexte élargi de la perte et la revivification des langues autochtones. Je discute de trois enjeux d'éthique liés entre eux: le rapport entre le dialecte que parlent les élèves autochtones et la langue ancestrale qu'ils ne parlent plus; les répercussions éducatives d'avoir des autochtones anglophones dans la salle de classe; la problématique initié-non initié découlant du fait d'avoir un chercheur anglophone œuvrant dans les domaines de l'éducation et de la langue autochtones. Je fais également une analyse documentaire portant sur l'anglais autochtone et je dresse les grandes lignes des changements qui ont eu lieu dans les pratiques en salle de classe. Alors que dans le passé, l'objectif commun était d'éliminer le dialecte local, celui des programmes actuels est d'ajouter l'anglais standard comme dialecte additionnel au répertoire de variétés linguistiques des élèves. J'offre des suggestions aux enseignants qui aimeraient employer une approche bidialectale en classe.

\section{Introduction}

The title for this article comes from a section in Heit and Blair's (1993) chapter "Language Needs and Characteristics of Saskatchewan Indian and Métis 
Students: Implications for Educators." Thirty years ago, I arrived for my first teaching job in a small, remote, predominantly Aboriginal community in the Cariboo-Chilcotin region of British Columbia. I had decided to become a teacher when I was 7 years old, and I could hardly wait to begin my new position. On my first day in the community, a group of curious children from the nearby reserve came to welcome me at the duplex situated on the school ground, which I shared with the new principal and his wife. In conversation, the children referred to the new principal as "he" and "him." Then I heard one of the children referring to me as "him" and to the principal's wife in the same way. Surprised and confused, I wondered what was happening. They had been calling me Miss Wiltse; why were they referring to me as he? It is with shame that I recall thinking, "What is the matter with these kids? And what have I got myself in for here?"

In fact, the lack was mine. In time, I learned that these children were speaking a dialect of English known variously as Indian, Aboriginal, Indigenous, or First Nations English. Fifteen years later, after having taught in three Aboriginal communities, I completed my master's thesis on Aboriginal language loss and revival. One of the readings that featured prominently in my studies (and in my thesis) addressed the language needs and characteristics of Saskatchewan Indian and Métis students (Heit \& Blair, 1993). The following, from a section entitled "But My Students All Speak English": The Nature of Dialects, brought back powerful memories and regrets of that first teaching anecdote.

As in many Indigenous languages, Cree classifies things according to whether they are animate or inanimate, and not according to a gender that is masculine, feminine, or neuter as in English. Thus Cree students learning English will frequently use "he" when they mean "she." (p. 119)

The authors go on to explain that many Native (and Métis) students speak a comprehensive dialect of English that is the result of the influence of the Indigenous language or mother tongue on the English language. There was a perfectly logical explanation for my students' language use; although they spoke Carrier, a Northern Athabaskan language spoken in the central interior region of British Columbia rather than Cree, the classification example applied. I wondered how different my initial teaching experiences might have been for both my students and me had I been exposed to knowledge of this nature in my teacher education program rather than learning later on the job by trial and error.

Before continuing with my discussion, I need to mention that terminology has proved challenging in this article. Although for the most part I use the term Aboriginal English, I make reference as well to Indigenous, First Nations, or Indian English depending on the context and in particular the source to 
which I am referring. In this regard, the date of publication is a significant factor. For example, when I first researched this topic years ago for my master's thesis, the term Indian English was not uncommon; as language use has changed over the years, the term Indian is less often used in Canadian contexts. However, in the Heit and Blair (1993) chapter that was the catalyst for this article, the authors use the term Indigenous English. The place of publication is also important. In terms of region, Indian English is still often used in a United States setting. Aboriginal English refers to the variety spoken by Aboriginal peoples in Australia (in addition to Canadian Aboriginal speakers). In one of the sources describing speakers from British Columbia, the non-standard variety is referred to as First Nations English. I acknowledge that potential problems are associated with each term used. A similar situation applies to the speakers of these language varieties, with various authors referring to Indian, Métis, Indigenous, or First Nations students. Although I realize that legal and other differences are associated with these terms, I use the term that is most appropriate for the particular context that I am addressing.

At the time, however, I knew nothing about the dialect spoken by my students; in fact, I was largely unaware of the distinction between language and dialect and the politics that attach to these words. In their work, Heit and Blair (1993) summarize the research on dialectology. For the purposes of this article, I briefly mention select key points (see pp. 112-115 for a more detailed description): the term dialect refers to any given variety of a language shared by a group of speakers; dialects are variations of a single language, exhibiting varying degrees of differences in the areas of pronunciation, grammar, vocabulary, and discourse patterns; dialects are a result of regional and social distinctions and can also reflect the influences of people's mother tongue; although dialects of English have been shown to be legitimate, systematic, and rule-governed, they are not all accorded equal status. Toohey (1986) explains that a standard dialect is usually defined as that variety of a language that is considered appropriate for communication over a wide area; that is used in institutions, radio, television, and newspapers, and that is usually taught in schools; and is usually the mother tongue of the educated middle class. Speicher and Bielanski (2000) note that although linguists argue that no dialect is inherently superior to another (Baugh, 1983; Labov, 1970; Trudghill, 1994), from a social standpoint, studies demonstrate that even people who do not speak the standard judge the standard superior to other dialects (Dose \& Gross, 1994; Speicher \& McMahon, 1992). "There is no doubt that the dialect of English which has the highest social status is the dialect which is widely known as Standard English" (Trudgill, p. 5). Other varieties of English, for example, Indigenous English, are referred to as non-standard dialects, varieties, or Englishes. Although I recognize that the term dialect is increasingly being replaced by either of the expressions language varieties or Englishes, I use the term dialect for the most part because of the literature from which I 
am drawing. Unfortunately, I learned neither about dialect in general nor about Indian English in particular during the teacher preparation program I took at the University of Victoria. Until I began to teach in a cross-cultural context, I had no idea how ill prepared I was for the position I had accepted. That first challenging yet profound teaching experience has since driven and shaped my teaching and academic career.

The call for submissions for a special issue of TESL Canada Journal on perspectives on ethics in cross-cultural, cross-linguistic research provided the impetus for me to think about the ethical issues in relation to the topic of Aboriginal students who speak a dialect of English (and may be referred to as [Standard]-English-as-a-Second-Dialect or [S]ESD learners). Although I had not purposely framed the matter in ethical terms, on consideration I realized that there was no shortage of ethical issues related to the reality that my former students spoke a dialect of English and that I was, at least initially, ignorant of this important information. My article takes a somewhat different slant to addressing the special issue call, but one that addresses ethical issues in cross-cultural, cross-linguistic research nonetheless. The interrelated ethical issues that are discussed are threefold: (a) How did my students come to be speakers of Aboriginal English in the first place? (what are the implications of realizing that the dialect had replaced an ancestral language?); (b) What are the educational implications of Aboriginal English in the classroom (what misunderstandings might arise, why is there a general lack of information, and so forth)? (c) Why am I, a non-Aboriginal English-speaking researcher, working in the areas of Aboriginal education and language (how does the insider-outsider debate in cross-cultural, cross-linguistic research apply in this particular context)?

The call for submissions provoked a number of personal and professional questions: in addition to those mentioned, I wondered how much had changed in the 30 years since I had made my dialect blunder and the 15 years since I wrote about it in my thesis. Accordingly, I chose to revisit one of the chapters "But My Students All Speak English," from my master's thesis, but to do so with the ethical questions framing my investigation. A current review of the related literature to determine changes in the field augments my retrospective inquiry.

\section{Why Did All My Students Speak English?}

The first ethical issue relates to the sad reality not that my students (and so many other Aboriginal students) spoke English, but that they did so at the expense of an ancestral language that was spoken by family members in earlier generations. Although the complex subject of Aboriginal language loss, maintenance, and revitalization is beyond the scope of this article, a connection between the topic and that of Aboriginal English merits mention. Ball and Bernhardt (2008) make the pertinent point that "First Nations English 
dialects are situated within an overall context of language loss and revitalization in Canada" (p. 571). Although "before colonization there were about 63 languages in Canada belonging to 11 different language families" (Bear Nicholas, 2009, p. 221), during the past 100 years or more, nearly 10 onceflourishing languages have become extinct, and at least a dozen are on the brink of extinction. It is estimated that approximately 50 Indigenous languages are currently spoken in Canada; of these, Cree, Ojibwe, and Inuktitut have the largest numbers of speakers and are the only languages not considered endangered (Sarkar \& Metallic, 2009). Although various factors have led to the loss and endangerment of Canada's Aboriginal languages, the role of residential schools and their residue have been particularly destructive.

By way of illustration, I introduce Kelly (a pseudonym), the teacher of the Junior High Native Awareness class in an urban school where I conducted research for my master's thesis on Native language loss and revival. Kelly and I met in a Native studies course at the University of Alberta. A shared interest in Native language issues led to my conducting my study in her Native awareness class. At the time of the study, Kelly was a consultant and Native liaison for Edmonton Public Schools in conjunction with the Sacred Circle Project, which was developed to address the needs of Native urban students.

The field site was one where students had expressed an interest in learning Native languages although none was officially taught. The purpose of the study was to explore the source of this interest and to consider how the interest could be brought to fruition. I visited the class weekly as a participant observer and then conducted interviews with Kelly and a number of students as the course was drawing to a close. Kelly and I had many conversations during the course of the project; as the Native awareness class was the last class on Friday afternoons, we usually went for coffee afterward to debrief. The interview, which was audiotaped and transcribed verbatim, provided the opportunity for me to record her story in her own words. In the following interview segment, Kelly explains why she and her siblings do not speak Cree, even though their father was a fluent Cree speaker. I draw on select data from Wiltse (1995) The River Flows Both Ways: Native Language Loss and Revival.

Well, because of residential schooling, that's the main reason for all of us not speaking Cree because when my Dad went to residential school, there were big signs all over the place that there was to be no Indian spoken. He told us, "We always wondered what kind of language that was because we spoke Cree; we didn't know what Indian was." But they were beaten for speaking their language and even as a really young man he vowed if he ever had kids that he'd never teach them how to speak Cree. (p. 68)

In Resistance and Renewal: Surviving the Indian Residential School, Haig-Brown (1988) suggests that perhaps the school's biggest effect on language use could 
be called secondary. Although punishing children for speaking their mother tongues did not eradicate their languages, many of the children as adults made the conscious choice not to pass their Native languages on to their children so that their children might avoid the punishments incurred through using an Aboriginal language at school. Another powerful example can be seen in the foreword to Haig-Brown's book where she quotes Randy Fred recounting the past horrors and lingering effects of residential schools:

The elimination of language has always been a primary stage in a process of cultural genocide. This was the primary function of the residential school. My father, who attended Alberni Indian Residential School for four years in the twenties, was physically tortured by his teachers for speaking Tseshaht: they pushed sewing needles through his tongue, a routine punishment for language offenders. (pp. 15-16)

Randy's entire family was affected by the needle tortures that his father endured. His father's attitude became, "Why teach my children Indian if they are going to be punished for speaking it?" The result in Randy's words is expressed thus: "I never learned to speak my own language. I am now, therefore, truly a 'dumb Indian'" (p. 12).

Returning to my master's thesis research, in like vein Kelly furthers her explanation of her father's decision: "Back then he couldn't see times changing. That was bad for us because it would have been better instead of having to learn Cree at an older age. Then maybe we could have taught it to our kids." At the time of the study, Kelly, who was then in her 30s, was enrolled in Cree classes at the University of Alberta. Not being able to speak Cree appeared to have had a detrimental effect on Kelly's position as the liaison between schools and Native families, at least in her perception.

I guess that's where I kind of fail because a lot of times our parents don't always understand what the school is trying to tell them and I think that they'd probably understand better if I could speak Cree with them. Our older people, they feel so much more comfortable talking in Cree. (p. 35)

The punishments described here and the resultant secondary effects experienced by Kelly, my students, and countless others comprise a serious ethical issue. For contemporary Aboriginal students, the expectation that they speak English is not negative in itself; there is consensus that being proficient in English is necessary for success in school and beyond. (Although this article is situated in an English-language milieu, it is important to note that a similar argument could be made about the French context for students living in Quebec.) What is problematic, though, is that the learning of English has all too 
often resulted in the loss of ancestral languages. Unfortunately, many immigrant groups experience this reality as well. Although I cannot do justice to the multifaceted educational implications of this grim reality here, Smolkin and Suina (1996) capture the dual nature of the effects of minority first-language loss in their article "Lost in Language and Language Lost." Native students are often lost in language at school; in many ways this is related to their lost language.

Although Kelly's father "couldn't see times changing," thankfully there have been changes (although much more needs to occur for a substantive difference to be made). Although a number of languages are now extinct and others endangered, many efforts are being made to maintain and revive Aboriginal languages (Ball, 2009; Fishman, 2001; Hinton \& Hale, 2001; Norris, 2006; Sarkar \& Metallic, 2009). It is another albeit related issue that is at the heart of this article, that of Aboriginal English.

\section{Ancestral Language Base}

In an article published in 1986, Toohey explained that although there had been no extensive documentation of the characteristics of the English speech of Native people, the assumption that distinctive Indian English (her term) codes existed in Canada was pervasive. In a more recent review of the literature, Fadden and LaFrance (2010) reported that although Craig (1991) and Leap (1993) provided relatively thorough accounts of Aboriginal English varieties in the US, Aboriginal varieties of English have been given little attention in the Canadian context.

Fadden and LaFrance (2010) recount the origins of Aboriginal English: these varieties "date back to the time of contact with Europeans, when linguistic codes arose, merging features of Indigenous languages with the language of the colonizers" (p. 144). As English and Indigenous populations came into contact, First Nations English dialects probably developed as lingua francas; these dialects are "shaped by cultural patterns of communication, by phenomena associated with languages in contact, and by the linguistic features of Indigenous languages" (Ball \& Bernhardt, 2008, p. 573).

In the absence of detailed research related to Aboriginal English varieties in Canada, Leap's (1993) extensive study American Indian English provides applicable background information on the subject. Leap suggests that in the US there are probably more than 200 Indian Englishes spoken given the contrasts in Indian English usage associated with age, gender differences, schooling, work, and residential schooling experiences. According to Leap, rules from ancestral language grammar and discourse give Indian English grammar and discourse their uniquely expressive, distinctively Indian, and tribe-specific properties. In support of his argument, he notes that in all his research sites he has found evidence of individual original Aboriginal language influences on "Indian English sound systems, word constructions, 
sentence forms, reference structures, and usage strategies" (p. 93); importantly, these sites include settings where "Indian English speakers are not fluent speakers of their ancestral languages and where Indian English becomes the only contact speakers have with their tribe's verbal tradition" (p. 93). The significance of this, he suggests, is that "Indian English is the first language learned by two-thirds of today's American Indian youth. For more than twothirds of them, Indian English is the only Indian-related language that they know" (p. 282). Ball and Bernhardt (2008) locate Aboriginal English varieties on an "uneasy margin between language loss and language revitalization" (p. 573): "On the one hand, First Nations dialects reflect a historical situation in which English has been, and remains, a major colonizing language; on the other hand, the dialects are important linguistic markers of Indigenous identity and solidarity" (p. 573). They go on to explain that these First Nations English dialects may ironically play an important role in efforts to revive Aboriginal languages and identities; as First Nations English dialects may echo aspects of an endangered language, "fluency in the First Nations English dialect can provide speakers who want to learn or re-learn an ancestral language an easier point of entry" (p. 575).

In addition to possible benefits, Leap (1993) outlines potential negative aspects to speaking Indian (or Aboriginal, First Nations, Indigenous) English:

Indian English fluency becomes problematic for speakers in classrooms, the workplace, and other settings where the language of the metropolis (or other, non-Indian English codes) sets the "standards" against which fluency and proficiency are to be judged. (p. 282)

An example of this can be evidenced in Kelly's comment, about her father's English:

When I went to school, I remember when my Dad was speaking English, he used to call the girls he, and I would always tell him, "You know Daddy, girls are she and guys are he." And, so for a while he would call him he, but an hour later he would fall back to calling him she. And, I just thought, "What's the matter with this old guy?" But, in Cree, there's one word for the way we differentiate gender and things are just animate or inanimate, you're one or the other and so it wasn't he or she. And, I would have never corrected him, if I had known then what I understand now. (p. 35)

Not surprisingly, when Kelly told this story, I was reminded of my mistake regarding contrasting classification systems between languages. Leap's (1993) explanation about ancestral language base and knowledge about classification in Cree helped me to understand that Kelly's father was speaking an English variety influenced by his mother tongue, Cree. Kelly relates the point to her students: 
It always seems that we have to be grammatically correct and I sometimes correct the kids in school. They never use he and she incorrectly, but just other little words I may correct them about. But you know, when I think back on what I did to my Dad I keep thinking that somehow or other, these kids are Cree speakers. Even if their parents don't speak Cree at home, their parents did, and so that influence is coming from an earlier generation. Even I have a hard time with English and I never spoke Cree. (emphasis added, p. 38)

When Kelly muses, "Somehow or other, these kids are Cree speakers," she does not use the term dialect; however, she means that her students are speakers of Cree English. Kelly's comments indicate that this influence extends into the next generation, corresponding with Leap's (1993) insistence that speakers of Indian English are to be found in places where Indian English-speakers are not fluent speakers of their ancestral languages:

It is important to stress that the native system does not depend on speaking a Native language. Cree English retains a basically Cree semantic system and is used in Cree interactional contexts. Language code is, then, a trivial determinant of communicative effectiveness. In fact, the Native person whose first or only language is English may be subject to greater communicative difficulty simply because both parties to interethnic communication assume incorrectly that they speak the same language. (Darnell, 1985, p. 63)

The assumption inherent in the title of this article But My Students All Speak English provides an apt example of Darnell's point about communicative difficulty. Fredeen (1991) explains that the prevailing view among many Canadian educators that English has completely replaced Indigenous languages can be detrimental; although some Native students may appear to be fluent in English, they may not have the type of proficiency in English that is necessary for academic success. These students may need exposure to a significant amount of intensive language teaching, yet Native students receive no systematic teaching of English as a second language (Toohey, 1985). This certainly resonates with Kelly's experience as evidenced here.

I guess because we happen to be born in Canada, teachers seem to think that we should be able to speak perfect English. However, they don't realize that for a lot of our students, English is their second language. There isn't an English as a second language program for Cree speakers, but there should be. So, I think that maybe when we're doing language arts that we should not only have ESL for immigrants but also for Native Canadians. (p. 38) 
At this point, it is important to note that there is great diversity in the communities where Native students live across Canada. For example, referring to the Saskatchewan context, Heit and Blair (1993) outline six possible speaker positions for Indian and Métis students. They may be: (a) monolingual in an Indigenous language; (b) monolingual in standard English; (c) monolingual in a dialect of English; (d) bilingual in an Indigenous language and English; (e) speak an Indigenous language and some degree of English; or finally (f) speak a non-standard dialect of English and some degree of an Indigenous language (see p. 105 for a more detailed description of these positions). Another possibility that could be added to the list is that students could be bi-dialectal in Standard English and an Indigenous English.

English is a second language for the increasingly small number of students who speak an Indigenous language as their mother tongue; these students for the most part live in remote communities. These are the learners who would benefit from, but who for a variety of reasons typically do not receive, English-as-a-second-language (ESL) programming. Other students, especially those in urban centers, usually learn English as their first language; many, but by no means all, these students speak a nonstandard dialect of English, a form of Aboriginal English. For these students, standard-Englishas- a-second-dialect (SESD) programming would be the appropriate choice. Ball (2009) describes the additive approach that is needed for both types of students:

Indigenous children whose home language is either a nonstandard variant of English or French or an Indigenous language, need transition programs to support ongoing acquisition of the language(s) or dialect(s) they have at school entry while preparing them to succeed in the language of instruction. (p. 31)

Given the current situation in which large numbers of First Nations languages are on the brink of extinction, there are more Aboriginal students in Canadian schools who speak English as a second dialect than there are those who speak an ancestral language as a mother tongue. The following section focuses on ethical concerns related to how dialect is enacted in the classroom.

\section{Pedagogical Considerations}

One of the ethical issues that I raise at the beginning of the article relates to the pedagogical concerns surrounding the statement "But my students all speak English." I examine two broad themes: the problems (the lack of knowledge and the misunderstandings) and suggestions (implications for classroom practice). 


\section{The Lack of Knowledge}

At the time of the teaching incident 30 years ago that sparked this article, the subject of Aboriginal English was not common knowledge for Canadian educators. When I researched the topic of Aboriginal Englishes several years later for my master's thesis (referred to more frequently then as Indian or Indigenous English), I learned that compared with other language minority groups, relatively little information was available. Burnaby (1987) raised this concern in her article "Language for Native, Ethnic, or Recent Immigrant Groups: What's the Difference?"

The situation of Native people will receive the most prominence in the discussion. The reason for this balance is that the Native group is the smallest of the three, and its characteristics are the least wellknown in the field of Canadian education. Thus, if awareness is to be raised in a paper such as this one about commonalities or unique needs in Canadian language education, providing information about the Native situation should be a priority. (p. 10)

Referring more specifically to the topic of Native Canadians who speak a dialect of English, Toohey (1986) compares the circumstances surrounding Indian English to Black English in the US, noting that the hypothesis that some North American Native people speak nonstandard dialects of English is comparatively recent. In many contexts, the term African American Vernacular English (AEVE) has replaced the term Black English; this provides another example of how terminology changes over time. This was certainly reflected in the literature at the time; although there was a substantial amount of information about Black Englishes and the Ebonics debate, there was relatively little about Aboriginal forms of English, still less that dealt with the issues from a Canadian perspective. As the articles by Burnaby and Toohey were published in 1987 and 1986 respectively, it is reasonable now to question whether the situation has changed significantly in the last 25 years. I have ascertained in the past few months that when knowledge about Aboriginal ancestral languages is compared with knowledge about other language minority populations, the circumstances are similar to the results from a quarter decade ago. Perhaps owing to the influx of immigrants to Canada in the last two decades and the consequent pressure of numbers, much of the recent research examining minority-language learning and teaching has been conducted with English-language learners who are recent immigrants and live primarily in urban centers (Goldstein, 2003; Haneda, 2005; Lotherington, 2007; Schecter \& Cummins, 2003).

During this time also, a significant amount of research has been conducted with speakers of non-standard English language varieties and dialects (Adger, Wolfram, \& Christian, 2007; Blake \& Cutler, 2003; Haig \& Oliver, 
2003; Hopson; 2003; Lee, 2004). However, much of this research has focused on AEVE. The needs of other students who speak non-standard English varieties, in particular Canadian Aboriginal students, have not been adequately represented in the extant research. However, it is encouraging to note that a literature review conducted for the purpose of this article shows recent Canadian research conducted on the topic of Aboriginal students who speak a language variety other than the standard (Ball, 2009; Ball \& Bernhardt, 2008; Battiste, Friesen \& Krauth, 2009; Epstein \& Xu, 2003; Fadden \& LaFrance, 2010; Sterzuk, 2008). I elaborate on some of this research below.

\section{Assumptions and Misunderstandings}

In addition to the lack of information about the nonstandard varieties of English spoken by Aboriginal students are various assumptions and misunderstandings about students who speak Aboriginal English. These include, but are not limited to: the dialect spoken is mistaken for some type of language impairment; the dialect spoken is inferior and should be replaced by Standard English; and the related belief that students have no need for nonstandard varieties. It seems that generally speaking, teachers, at least those from the dominant English-speaking culture, consider Aboriginal dialects to be either an impairment or an inferior form of speech. In either case, students who speak Aboriginal English are deemed deficient in some way. A reflection of this attitude can be found in Kelly's comments:

Our older people, they feel so much more comfortable talking in Cree. If they have a really heavy accent of being a Cree speaker, they may be embarrassed about their accent. When people have a different kind of accent, like English (from England) or Scottish or Australian, people say that it sounds so nice, but when you have a Cree speaker with a really heavy accent people laugh. They have made fun of it for years and they still do. So, our Native people aren't always that anxious to speak English. (pp. 35-36)

In the above excerpt, Kelly continues her discussion about the discrimination that Cree speakers face in speaking English. Although this injustice is not limited to Cree, it is certainly a legitimate concern. I personally have witnessed people's positive comments about certain accents that are perceived to be "classy" or "seductive" or "friendly"; at the same time, I have heard derogatory jokes told in or about Aboriginal English (or other denigrated dialects). Kelly feels inadequate in the Native community because she does not speak Cree, whereas Cree-speakers may feel inadequate in the dominant society because of how they speak English.

Wolfram and Christian (1989) make the point that

language prejudices seem more resistant to change than other kinds of prejudice. Members of the majority culture who would be quite 
willing to accept equality in other social and educational areas may continue to reject the legitimacy of a dialect difference. (p. 19)

Lippi-Green (1994) argues that discrimination based on speech patterns "is the site on which racism and ethnocentrism are institutionalized" (p. 191). Unfortunately, the classroom is no exception; Heit and Blair (1993) speak to the importance of teachers' attitudes to students' language:

The lack of knowledge about second language learning and the nature of dialects has led and will continue to lead to misunderstandings and miseducation of Indian and Métis students when language differences are interpreted as language deficiencies, or when they lead to the formation of stereotypes or misjudgments of someone's ability on the basis of his/her spoken language. (p. 121)

Although the distinctive characteristics of spoken Indigenous English (or other non-standard dialects) are dialectal differences, not evidence of speech deficit or language impairment, students whose community language patterns are different from those of the mainstream community have often been diagnosed as having disorders of various types. For example, in her research into English dialect-speaking Indigenous students, Sterzuk (2008) found a disproportionate representation of First Nations and Métis students in remedial language and speech programs in Saskatchewan schools. Also, drawing on an earlier study conducted in British Columbia (Ball, Bernhardt, \& Derby, 2006), Ball and Bernhardt (2008) suggest that First Nations children may be "disproportionately diagnosed with speech-language impairments, which in turn may stem in part from misrepresentations of aspect of Native children's home English dialects as evidence of speech-language deficits or delays" (p. 570). They make the crucial point that in order for students to receive appropriate treatment and teaching, speech-language pathologists and educators need to be able to differentiate language difference (in this case, dialect) from language impairment.

Delpit (1995) speaks to a somewhat different, but also significant, aspect of teachers' attitudes to students' language use. Teachers unfamiliar with the language abilities of their students who speak a non-standard dialect may allow students to stay at a basic level because they do not understand the language competence that their students already possess. On this note, Toohey (1986) urges teachers to learn something of what their students know and of how their students frame that knowledge:

I have argued that mere documentation of how our students' dialects differ from standard in a surface structural sense is not enough. It is rarely the surface structural differences which confuse or terminate conversations between, for example, Native students and non-Native teachers. (p. 142) 
Although I wish I had been informed about some of the structural differences when I was teaching in Anahim Lake, what Toohey says makes a great deal of sense to me. The questions remain, then, what are the deeper structural differences, and what knowledge of those is pedagogically useful?

\section{The Need for an Additive Approach}

Ironically, the more determined we are to rid the school of children's home language, the more determined they must become to preserve it. Since language is one of the most intimate expressions of identity, indeed, "the skin that we speak," then to reject a person's language can only feel as if we are rejecting him. (Delpit, 2002, p. 47)

In addition to the misunderstandings and misdiagnoses mentioned is the concern that many teachers do not understand that students need to have their home dialect (or language) embraced in school in addition to learning Standard English. Leap (1993) advises teachers to "recognize that Indian English is not a marker of language deficiency and that being fluent in these codes does not prevent speakers from acquiring fluency in other varieties of English" (p. 284). Similarly, Fadden and LaFrance (2010) explain that if teachers are unaware of the linguistic legitimacy of an Aboriginal English dialect, they may be unlikely to encourage its use; rather, they may focus only on "children's acquisition of standard school dialects of English ... without including instruction to maintain or develop the proficiency of their child's Indigenous language or their home dialect of English" (Ball, 2009, p. 36).

There is agreement that students need competence in Standard English to function effectively in school and in other settings (Delpit, 2002; Leap, 1993) and that Standard English should be taught in schools, especially because students who do not have access to Standard English are less likely to succeed economically (Delpit, 2002; Speicher \& Bielanski, 2000). Referring specifically to Indian students, Leap argues that they also

need proficiency in the Indian English code(s) of their home community ... in order to function effectively in those domains. To be avoided, then, are classroom activities that require Indian students to renounce Indian English-related proficiency before they can develop Standard English skills. (p. 284)

Until recently, educational programs have focused on teaching Standard English to Aboriginal students; the goal of current programs should be to add Standard English as a second dialect to their repertoire of linguistic varieties rather than to eliminate the home dialect: in other words, educators need to take an additive approach (Epstein \& Xu, 2003).

For educators interested in using a bi-dialectal additive approach, the literature provides models to look to for guidance. For example, in her study 
on the use of AAVE as a resource in the classroom, Lee (2004) describes an apprenticeship into literary response in a high school serving African-American students who are speakers of AEVE. Although AEVE has been long viewed as a detriment, Lee's research focused on how students' language resources supported learning. In the Hawaiian context, Davis, Bazzi, Cho, Ishida, and Soria (2005) report on a school program that promotes the use of Hawai'i Creole English in conjunction with Standard English for academic purposes. In Australia, a bi-dialectal approach (community language and Standard Australian English) has been used in Australian schools for more than two decades (Malcolm, 2001; Walton, 1993). In Canada, Ball (2009) reports, "the potential of the ESD concept and ESD funding to evolve a strengths-based, culturally appropriate pedagogy to support Indigenous children's language and literacy is emerging as a topic of considerable interest among educators" (p. 31) in several provinces. Although I am encouraged by these initiatives, I am aware that the work that must be accomplished has just begun.

Regrettably, little has changed in terms of this information reaching preservice teachers and in many cases inservice teachers. Heit and Blair (1993) note,

a great deal of damage has been done to Indian and Métis students ... due to differences in their spoken English that have been misunderstood by educators, who, through no fault of their own have not been trained in these areas. (pp. 115-116)

Although they are referring to the Saskatchewan context, this statement certainly applies to my beginning teaching experience in British Columbia. On the other hand, the argument that the fault was not mine as I had not learned about these topics in my teacher education program feels like insufficient justification for the harm I might have done. In the Alberta context, I return to Kelly, who offers her opinion on inservice sessions for those already teaching:

And I just think that our teachers need to get a grip and understand that there's a difference between Cree and English. You know, they all wonder why Native students do so poorly and yet when we have a Native Awareness workshop or inservice, there/s usually more Native liaison workers there than there are teachers. So I told them I wasn't going to humor anybody anymore by putting on an inservice when there was more liaison workers there than there was people from the district. (p. 36)

I am in no position to make judgments or generalizations; yet Kelly's comment is perturbing. I am left wondering where to draw the line between ignorance and accountability. Who is to blame? And perhaps more to the 
point, who will take responsibility for trying to ensure that the research and knowledge about non-standard English varieties that is now available and accessible reaches teachers both preservice and inservice? This question brings me to the third ethical issue, that of a non-Aboriginal person working in the field of Aboriginal education.

I have struggled with this dilemma in one way or another for 30 years as a schoolteacher, as a researcher, and as a teacher educator. When I wrote my master's thesis, I identified strongly with Haig-Brown's (1992) article "Choosing Border Work." As a non-Native person, she agonized over the suitability of centering her research in First Nations education; so did I. Despite my dedication, so great was my discomfort that after completing my master's degree, I turned my back on this area for what I felt were ethical reasons; I have returned to the topic for ethical reasons of another nature. Although I expect that this will remain a place of discomfort for me (as it should), researching and writing this article has resulted in a slight shift in my location on my own "uneasy margin." My commitment to the importance of this littleknown and oft-neglected topic has strengthened; I am aware how well positioned I am to make a difference in increasing its profile in teacher education.

This is in keeping with Speicher and Bielanski's (2000) appeal that "linguists and other educators must disseminate knowledge of dialects much more broadly than they currently do to combat the unquestioned discrimination that occurs linking language usage to social mobility, educational advancement, and personal traits" (p. 165). Although they are referring to the US context, I suggest that the need for such knowledge in Canada is just as pressing, if not more so, as the issue is much less well known.

As I proceed in this area, I work according to the important ethical issues that apply to those who conduct cross-cultural, cross-linguistic research. Foremost among these concerns is an increasing recognition of the need to decolonize research in cross-cultural contexts (Apffel-Marglin \& Marglin, 1996; Mutua \& Swadener, 2004; Smith, 1999). Ball and Bernhardt (2008) outline some of the principles involved in decolonizing research for those working with First Nations communities: investigators need to step down from the role of "expert"; the various kinds of expertise brought by investigators and participants must be mutually acknowledged; First Nations communities should take part in planning and conducting the research; the research must directly benefit the participants; and research findings need to be disseminated in clear language and made accessible to the community (see pp. 582-583 for further discussion). I am no longer the uninformed young teacher who unfairly misjudged her first students 30 years ago; I have learned many hard lessons about cross-cultural, cross-linguistic teaching and research. I know that if I hope to contribute to the much-needed work in the field of Aboriginal language issues, any research I do "needs to be carried out ... in ways that respect the communities' culture and goals" (p. 582). 


\section{The Author}

Lynne Wiltse is an associate professor in the Department of Elementary Education at the University of Alberta where she teaches courses in language and literacy and children's literature. Previously she taught at Thompson Rivers University in Kamloops, BC. Her research interests include minority language education, Aboriginal education, multicultural children's literature, sociocultural theory, teacher education, and qualitative methodologies.

\section{References}

Adger, C., Wolfram, W., \& Christian, D. (2007). Dialects in schools and communities (2nd ed). Mahwah, NJ: Erlbaum.

Apffel-Marglin, F., \& Marglin, S. (1996). Decolonizing knowledge: From development to dialogue. New York: Clarendon.

Ball, J. (2009). Supporting young Indigenous children's language development in Canada: A review of research on needs and promising practices. Canadian Modern Language Review, 66(1), 19-47.

Ball, J., \& Bernhardt. B. (2008). First Nations English dialects in Canada: Implications for speech-language pathology. Clinical Linguistics and Phonetics, 22, 570-588.

Ball, J., Bernhardt, B., \& Derby, J. (2006). First Nations English dialects: Exploratory project proceedings. Unpublished monograph, University of Victoria and University of British Columbia.

Baugh, J. (1983). Black street speech: Its history, structure, and survival. Austin, TX: University of Texas Press.

Battiste, M., Friesen, J., \& Krauth, B. (2009). Non-standard English at school: Can targeted funding improve student achievement? Unpublished manuscript, Simon Fraser University.

Bear Nicholas, A. (2009). Reversing language shift through a native language immersion teacher training programme in Canada. In T. Skutnabb-Kangas, R., Phillipson, A., Mohanty, \& M. Panda. (Eds.), Social justice through multilingual education (pp. 220-237) North York, ON: Multilingual Matters.

Blake, R., \& Cutler, C. (2003). AAE and variation in teachers' attitudes: A question of school philosophy. Linguistics \& Education, 14(2), 163-195.

Burnaby, B. (1987). Language for Native, ethnic, or recent immigrant groups: What's the difference? TESL Canada Journal, 4(2).

Craig, B. (1991). American Indian English. English World-Wide, 12(1), 25-61.

Crystal, D. (1987). Cambridge encyclopedia of language. Cambridge, UK: Cambridge University Press.

Darnell, R. (1985). The language of power in Cree interethnic communication. In N. Wolfson \& J. Manes (Eds.), Language of inequality. (pp. 61-73). New York: Mouton.

Davis, K., Bazzi, S., Cho, H., Ishida, M., \& Soria, J. (2005). It's our Kuleana: A critical participatory approach to language-minority education. In L. Pease-Alvarez \& S. Schecter (Eds.), Teaching and community: contributions of situated and participatory approaches to educational innovation (pp. 3-25). Mahwah, NJ: Erlbaum.

Dose, R., \& Gross, A. (1994). The effects of Black English and code-switching on intraracial perceptions. Journal of Black Psychology, 20(3), 282-293.

Epstein, R., \& Xu, L. (2003). Roots and Wings: Teaching English as a second dialect to Aboriginal students - A review of the literature. (ERIC Document Reproduction No. ED 476389)

Fadden, L., \& LaFrance, J. (2010). Advancing Aboriginal English. Canadian Journal of Native Education, 32, 143-15.

Fishman, J. (Ed.). (2001). Can threatened languages be saved? Toronto, ON: Multilingual Matters.

Fredeen, S. (1991). Sociolinguistic survey of Indigenous languages in Saskatchewan: On the critical list. Saskatoon, SK: Saskatchewan Indigenous Languages Committee. 
Goldstein, T. (2003). Teaching and learning in a multilingual school: Choices, risks and dilemmas. Mahwah, NJ: Erlbaum.

Haig-Brown, C. (1988). Resistance and renewal: Surviving the Indian residential school. Vancouver, BC: Arsenal Pulp Press.

Haig-Brown, C. (1992). Choosing border work. Canadian Journal of Native Education, 19(1), 96114.

Haig, Y., \& Oliver, R. (2003). Language variation and education: Teachers' perceptions. Language and Education, 17(4), 266-280.

Haneda, M. (2005). Some functions of triadic dialogue in the classroom: Examples from L2 research. Canadian Modern Language Review, 62(2), 313-333.

Heit, M., \& Blair, H. (1993). Language needs and characteristics of Saskatchewan Indian and Métis students: Implications for educators. In S. Morris, K. McLeod, \& M. Danesi (Eds.), Aboriginal languages and education: The Canadian experience (pp. 103-128). Oakville, ON: Mosaic.

Hinton, L., \& Hale, K. (Eds.). (2001). The green book of language revitalization in practice. New York: Academic Press.

Hopson, R. (2003). The problem of the language line: Cultural and social reproduction of hegemonic linguistic structures for learners of African descent in the USA. Race, Ethnicity, and Education, 6(3), 227-245.

Labov, W. (1970). The study of nonstandard English. Urbana, IL: National Council of Teachers of English.

Leap, W. (1993). American Indian English. Salt Lake City, UT: University of Utah Press.

Lee, C. (2004). Double voiced discourse: African American vernacular English as a resource in cultural modeling classrooms. In A. Ball \& S. Freedman (Eds.), Bakhtinian perspectives on language, literacy and learning (pp. 129-147). Cambridge, UK: Cambridge University Press.

Lotherington, H. (2007). Rewriting traditional tales as multilingual narratives at elementary school: Problems and progress. Canadian Journal of Applied Linguistics, 10(2), 241-256.

Lotherington, H., \& Chow, S. (2008). Rewriting Goldilocks in the urban, multicultural elementary school. In F. Shultz (Ed.) Multicultural education (14th ed., pp. 143-151). New York; McGraw-Hill. (Reprinted from The Reading Teacher, 60(3), 244-252.)

Malcolm, I. (2001). Two-way English and the bicultural experience. In B. Moore (Ed.), Who's centric now? The present state of post-colonial Englishes (pp. 219-240). New York: Oxford University Press.

Mutua, K., \& Swadener, B. (2004). Decolonizing research in cross-cultural contexts: Critical personal narratives. Albany, NY: SUNY Press.

Norris, M. J. (2006). Aboriginal languages in Canada: Trends and perspectives on maintenance and revitalization. In J. White, D. Beavon, \& S. Wingert (Eds.), Indigenous policy research: Moving forward, making a difference (Vol. 3, pp. 197-228). Toronto, ON: Thompson Educational.

Sarkar, M., \& Metallic, M.A. (2009). Indigenizing the structural syllabus: The challenge of revitalizing Mi'gmaq in Listuguj. Canadian Modern Language Review, 66(1), 49-71.

Schecter, S., \& Cummins, J. (2003). Multilingual education in practice: Using diversity as a resource. Portsmouth, NH: Heinemann.

Smith, L.T. (1997). Decolonizing methodologies: Research and Indigenous peoples. London: Zed Books.

Smolkin, L., \& Suina, J. (1996). Lost in language and language lost: Considering Native language in classrooms. Language Arts, 73(3), 166-172.

Speicher, B., \& Bielanski, J. (2000). Critical thoughts on teaching standard English. Curriculum Inquiry, 30(2), 147-169.

Speicher, B., \& McMahon, S. (1992). Some African-American perspectives on Black English Vernacular. Language in Society, 21, 383-407. 
Sterzuk, A. (2008). Whose English counts? Indigenous English in Saskatchewan schools. McGill Journal of Education/Revue des sciences de l'éducation de McGill, 43(1), 9-19.

Sterzuk, A. (2010). Indigenous English and standard language ideology: Towards a postcolonial view of English in teacher education. Canadian Journal of Native Education, 32, 100-113.

Toohey, K. (1985). English as a second language for Native Canadians. Canadian Journal of Education, 10(3), 275-293.

Toohey, K. (1986). Minority educational failure: Is dialect a factor? Curriculum Inquiry, 16(2), 127-145.

Trudgill, P. (1994). Dialects. London: Routledge.

Walton, C. (1993). Aboriginal education in Northern Australia: A case study of literacy policies and practices. In P. Freebody \& A.R. Welch (Eds.), Knowledge, culture and power: International perspectives on literacy as policy and practice (pp. 55-81). Pittsburgh, PA: University of Pittsburgh Press.

Wiltse, L. (1995). The river flows both ways: Native language loss and revival. Unpublished master's thesis, University of Alberta.

Wolfram, W., \& Christian, D. (1989). Dialect and education: Issues and answers. Englewood Cliffs, NJ: Prentice Hall Regents. 